\title{
Effects of Bengkoang (Pachyrhizus erosus (L) Urb Juice in Hampering Blood Glucose in Rat Models
}

\author{
Adrian Dwiputra Widyarman ${ }^{1}$, Emma Nurdiamah $^{2}$, Nanny Natalia Muliani Soetedjo ${ }^{3}$ \\ ${ }^{1}$ Faculty of Medicine, Universitas Padjadjaran, Bandung, Indonesia \\ ${ }^{2}$ Department of Pharmacology and Therapy, Faculty of Medicine, Universitas Padjadjaran, \\ ${ }^{3}$ Department of Internal Medicine, Faculty of Medicine, Universitas Padjadjaran/Dr Hasan Sadikin \\ General Hospital, Bandung, Indonesia
}

\begin{abstract}
Background : The prevalence of diabetes mellitus in Indonesia tends to increase and is predicted to reach 21.3 millions in 2030. Bengkoang (Pachyrhizus erosus (L) Urb. is one of the traditional medicine frequently used in diabetes treatment.The objective of this study is to assess the effectiveness of bengkoang juice in hampering blood glucose increase.

Methods : Fourty alloxan-induced diabetic Wistar rats were used in this study. After 16 hours of fasting, the blood glucose was measured using glucometer EasyTouch Blood Glucose/Cholesterol/Uric Acid MultiFunction Monitoring System. The positive control group was given $7 \mathrm{ml}$ of distilled water and $50 \%$ glucose solution with $2.5 \mathrm{~g} / \mathrm{kg}$ dosage while the study group were given $7 \mathrm{ml}$ of bengkoang juice and $50 \%$ glucose solution with $2.5 \mathrm{~g} / \mathrm{kg}$ dosage. Blood glucose was re-checked after 2 hours. This procedure was performed in October 2012.The results were analyzed using Student's T-test with $\alpha=0.05$.

Results : The result shows a significant difference in blood glucose increase between the control and study groups with a score of $121.11 \mathrm{mg} / \mathrm{dL}$ and $324.45 \mathrm{mg} / \mathrm{dL}$ respectively. This result shows that bengkoang juice increases blood glucose level in Wistar rats.

Conclusions: In conclusion, bengkoang (Pachyrhizus erosus (L) Urb. juice has no effect in hampering the blood glucose level increase in Wistar rats. [AMJ.2014;1(1):25-9]
\end{abstract}

Keywords: Alloxan, blood glucose, diabetes mellitus, Pachyrhizus erosus (L) Urb.

\section{Pengaruh Bengkoang (Pachyrhizus erosus (L) Urb Juice dalam Menghambat Glukosa Darah pada Tikus}

\begin{abstract}
Abstrak
Latar Belakang: Prevalensi diabetes mellitus di Indonesia cenderung meningkat dan diperkirakan mencapai 21,3 juta pada tahun 2030. Bengkoang (Pachyrhizus erosus ( $\mathrm{L}$ ) Urb adalah salah satu obat tradisional yang sering digunakan untuk pengobatan diabetes. Tujuan penelitian ini adalah untuk menilai efektivitas jus bengkoang dalam menghambat peningkatan glukosa darah.

Metode: Empat puluh tikus Wistar yang telah diinduksi diabetes aloksan digunakan dalam penelitian ini. Setelah 16 jam puasa, glukosa darah diukur dengan menggunakan glucometer Glukosa Darah EasyTouch / Kolesterol/Asam Urat Monitoring System Multi- Function. Kelompok kontrol positif diberi $7 \mathrm{ml}$ air suling dan larutan glukosa 50 \% dengan 2,5 g / kg dosis sedangkan kelompok studi diberi $7 \mathrm{ml}$ jus bengkoang dan larutan glukosa 50 \% dengan 2,5 g / kg dosis. Glukosa darah diperiksa kembali setelah 2 jam. Prosedur ini dilakukan pada hasil Oktober 2012 dianalisis menggunakan T -test Student dengan $\alpha=0,05$.

Hasil: Hasil penelitian menunjukkan perbedaan yang signifikan dalam peningkatan glukosa darah antara kelompok kontrol dan kelompok studi dengan skor $121.11 \mathrm{mg} / \mathrm{dL}$ dan 324,45 mg / dL masing-masing . Hasil ini menunjukkan bahwa jus bengkoang meningkatkan kadar glukosa darah pada tikus Wistar .

Simpulan: Bengkoang ( Pachyrhizus erosus ( L ) Urb jus tidak berpengaruh dalam menghambat kenaikan kadar glukosa darah pada tikus Wistar.

Kata kunci: Aloksan , glukosa darah, diabetes mellitus , Pachyrhizus erosus ( L ) Urb.
\end{abstract}

Correspondence: Adrian Dwiputra Widyarman, Faculty of Medicine, Universitas Padjadjaran, Jalan Raya BandungSumedang Km.21, Jatinangor, Sumedang, Indonesia, Phone: +6281298004423, Email: adrian.dwiputra92@gmail.com 


\section{Introduction}

Diabetes mellitus is a metabolic disease which is characterized by hyperglycemia caused by insufficient insulin production, decreased insulin effectiveness, or both. ${ }^{1}$ Diabetes mellitus is divided into several types, one of them is diabetes mellitus type 2 where the hyperglycemia is caused by insulin resistance. ${ }^{1}$

The classic symptoms of diabetes mellitus are polyuria, thirst, recurrent blurred vision, paresthesia, and fatigue. However, most of the diabetic patients have an insidious onset of hyperglycemia and appeared asymptomatic. The disease is usually detected during routine laboratory studies. ${ }^{1}$ The morbidity and mortality rate of diabetes mellitus is staggering. Diabetes mellitus is a disease with many dangerous complications such as renal disease, eye disease, nerve disease, heart disease, and stroke that lead to high financial expenditure. $^{2}$

Around 346 million people worldwide have diabetes mellitus. In 2004, it was estimated that there were 3.4 million deaths caused by diabetes mellitus and this number will increase two-fold by $2030 .^{3}$ In Indonesia, the number of diabetes mellitus patients will reach 21.3 millions by $2030 .{ }^{4}$ This estimation makes diabetes mellitus one of the world's important health problems because diabetes and its complication have a big impact to the economic and health sectors. ${ }^{3}$ In order to prevent the complication and to increase the quality of life of the patient, a good treatment method for diabetes mellitus is needed.

Currently, the treatment for diabetes mellitus type 2 depends on diet programs to prevent hyperglycemia and drugs to decrease the hyperglycemia, such as sulphonylurea, metformin, and biguanide. However, these drugs have several side effects such as hypoglycemia, body weight increase, gastrointestinal disturbance, and anemia5. Diet programs are also not effective because more than half of the diabetes mellitus patients fail to adhere to the program 1 . This situation leads to frequent use of herbal medicine by diabetes mellitus patients. ${ }^{6}$

Herbal medicine or phytomedicine is a treatment method using one or several parts of a plant. This method has already been used since ages ago along with conventional treatment. The herbal medicine use has increased during the last 30 years. Nevertheless, a consultation with a physician before using it is recommended because herbal medicine may cause allergic reactions or interact with other drugs. ${ }^{7}$ One of the herbal medicines used in for diabetes mellitus treatment is bengkoang.

Bengkoang (Pachyrhizus erosus (L) Urb is a plant in Fabaceae family. ${ }^{8}$ This plant originates from Mexico and have spread to several countries, including Indonesia. ${ }^{9}$ The plant consists of stem, leaf, flower, fruit, root, and tuber. The leaf's shape is varied and almost all parts of this plant are covered by fine hair except the flower. ${ }^{10}$ The tuber can weigh up to $2 \mathrm{~kg}$.

The tuber has many nutritional contents that are good for the body such as carbohydrate, protein, low fat, calcium, magnesium, phosphor, and several vitamins. ${ }^{10}$ The sweet taste comes from carbohydrates such as glucose, fructose, sucrose, and inulin. ${ }^{15}$ Inulin is also frequently used as glucose substitute in diabetic patient and dieting people. ${ }^{11}$ The tuber also contains a poisonous substance called rotenone which is frequently used as an insecticide, but this substance is only found in a very small amount. ${ }^{10}$

Bengkoang tuber is usually eaten ${ }^{12}$ or used as cosmetic ingredient for skin whitening or sunblock. ${ }^{13}$ It also has been used empirically to treat diabetes mellitus in the form of bengkoang tuber's juice which is consumed in the morning and before sleep. ${ }^{14}$ This effect is most likely caused by the inulin in the tuber juice that have low caloric value and has the effect of hampering glucose absorption in the intestines. ${ }^{11}$

The purpose of this study is to confirm the effect of bengkoang juice in hampering blood glucose increase in wistar strain rats.

\section{Methods}

This study used a laboratory experiment design and the subjects were male and female Wistar strain rats, weighed 150-200 gram, and were around 3 months of age.

Bengkoang tubers (Pachyrhizus erosus (L) Urb were acquired from Subang, West Java. The plant species identification is done by the Department of Biology, Faculty of Mathematics and Natural Sciences, Universitas Padjadjaran.

The bengkoang juice was made by following the traditional method. The tuber was washed first using clean water, peeled, and grated. The grated tuber was squeezed and filtered to get the juice. The amount given was $7 \mathrm{ml}$ based on the converted calculation using the conversion table based on the human dose. The juice was 
given orally.

The glucose was given to induce blood glucose increase so the bengkoang juice effect in hampering blood glucose increase could be assessed. Glucose was given in the solution form at $50 \%$ concentration and $2.5 \mathrm{~g} / \mathrm{kg}$ dose. The glucose was given orally. Alloxan was given in the solution form at $5 \%$ concentration and $125 \mathrm{mg} / \mathrm{kg}$ dose. Alloxan was given subcutaneously.

The wistar rats were kept in a standard cage for 1 week prior to study with free access to standard food and water. The rats were randomly divided into three groups. Diabetes was induced in 2 groups using 5\% alloxan solution at $125 \mathrm{mg} / \mathrm{kg}$ dose after 16 hours of fasting with free access to water. After 48 hours the fasting blood glucose level was checked through blood sampling from the tail vein. The sample was obtained by cutting the tip of the tail. The blood samples were tested using glucose test strip and glucometer, EasyTouch Blood Glucose/Cholesterol/ Uric Acid Multi-Function Monitoring System (EasyTouch GCU), and rats with fasting a blood glucose level greater than $100 \mathrm{mg} / \mathrm{dl}$ were included in the study.

Group 1 with non-diabetic rats were given $7 \mathrm{ml}$ of distilled water and glucose solution as the negative control group. Group 2 with diabetic rats were given $7 \mathrm{ml}$ of distilled water and glucose solution as the positive control group. Group 3 with diabetic rats were given $7 \mathrm{ml}$ of bengkoang juice and glucose solution as the study group.

After 2 hours, the blood glucose level was re-checked using the glucose test strip and glucometer as 2 hour post-prandial blood
Table 1 Blood Glucose Level Group 1 (Nondiabetic)

\begin{tabular}{cccc}
\hline \multicolumn{3}{c}{ Blood Glucose Level (mg/dL) } \\
\hline Fasting & $\begin{array}{c}\text { 2 Hours post- } \\
\text { prandial }\end{array}$ & Increase \\
\hline 95 & 106 & 11 \\
107 & 147 & 40 \\
95 & 125 & 30 \\
106 & 101 & -5 \\
90 & 130 & 40 \\
& 110 & 183 & 73 \\
95 & 145 & 50 \\
& 106 & 116 & 10 \\
Mean & 97.5 & 128.3 & 11 \\
\hline
\end{tabular}

glucose level. This procedure was performed in October 2012.

The results were expressed as Mean. The data were analyzed using Student's T-test with $\alpha=0.05$ to see the differences of blood glucose increase between the positive control group and the study group.

\section{Results}

The mean increase of blood glucose level is $121.11 \mathrm{mg} / \mathrm{dL}$ which is higher compared to Group 1 (Non-diabetic group / normal rats) (Table 2).

Table 2 Blood Glucose Level Group 2 (Diabetic not given Bengkoang Juice)

\begin{tabular}{cccc}
\hline & Blood Glucose Level (mg/dL) & \\
\hline Fasting & 2 Hours post-prandial & Increase \\
\hline 560 & 700 & 140 \\
167 & 250 & 83 \\
325 & 524 & 199 \\
515 & 700 & 185 \\
295 & 125 & -170 \\
321 & 414 & 93 \\
& 506 & 700 & 194 \\
190 & 566 & 466 \\
Mean & 135 & 125 & -10 \\
& 334.89 & 456 & 121.11 \\
\hline
\end{tabular}


Table 3 Blood Glucose Level Group 3 (Diabetic given Bengkoang Juice)

\begin{tabular}{ccc}
\hline & Blood Glucose Level (mg/dL) & \\
\hline Fasting & 2 Hours post-prandial & Increase \\
\hline 196 & 700 & 504 \\
295 & 541 & 246 \\
401 & 700 & 299 \\
506 & 700 & 194 \\
116 & 700 & 584 \\
286 & 484 & 198 \\
246 & 600 & 354 \\
243 & 566 & 323 \\
90 & 406 & 316 \\
325 & 700 & 375 \\
Mean & 700 & 176 \\
\hline
\end{tabular}

The mean increase of blood glucose level is $324.45 \mathrm{mg} / \mathrm{dL}$ which is even higher compared to Group 2 (Table 3).

In the normality test (Shapiro-Wilk), the $\mathrm{p}$-value was greater than 0.05 which means the data were normal. In homogeneity test (Levene Statistic), the p-value was greater than 0.05 which means the data were homogenous. In Student's T-test, the p-value was 0.004 , which means that there is a significant difference in blood glucose level increase between the positive control group and the study group.

\section{Discussion}

Inulin has a fiber-like effect ${ }^{11}$ that could hamper blood glucose increase. From the data shown in Table 2 and Table 3, the blood glucose level increase in the study group was greater than the positive control group. The t-test also shows a significant difference between both groups. These statements show that bengkoang juice increases the 2 hours pp blood glucose level in Wistar rats. This finding is probably caused by the carbohydrate contents, such as glucose, fructose, and sucrose, in bengkoang juice that causes higher carbohydrate intake. This higher carbohydrate intake causes an increase in blood glucose level. This finding also contradicts people's belief that bengkoang juice can be used to treat diabetes mellitus ${ }^{14}$ and the blood glucose hampering effect of inulin. ${ }^{11}$

Based on the analysis and discussions above, it can be concluded that bengkoang juice have no effect in hampering blood glucose increase in Wistar rats.

\section{Reference}

1. Gardner DG, Shoback DM, Greenspan FS. Greenspan's Basic \& Clinical Endocrinology. San Francisco: McGraw-Hill Medical; 2007

2. Williams RH, Larsen PR. Williams Textbook of Endocrinology. Philadelphia: Saunders; 2003.

3. WHO. Diabetes Fact sheet. 2012.[Cited 2012 April 12]; Available from: http:// www.who.int/mediacentre/factsheets/ fs312/en/index.html.

4. Departemen Kesehatan Republik Indonesia. Tahun 2030 Prevalensi Diabetes Melitus Di Indonesia Mencapai 21,3 Juta Orang. [Cited 2012 December 4]; Available from: http://www.depkes.go.id/ index.php/berita/press-release/414tahun-2030-prevalensi-diabetes-melitusdi-indonesia-mencapai-213-juta-orang. html.

5. Moller DE. New drug targets for type 2 diabetes and the metabolic syndrome. Nature. 2001;414(6865):821-7.

6. Al-Rowais NA. Herbal medicine in the treatment of diabetes mellitus. Saudi Med J. 2002;23(11):1327-31.

7. Ehrlich SD. Herbal medicine. 2011. [cited 2012 April 22]; Available from: http:// 
www.umm.edu/altmed/articles/herbalmedicine-000351.htm.

8. Integrated Taxonomic Information System. Pachyrhizus erosus (L.) Urb. Taxonomy and Nomenclature.2011. [Cited 2012 March 7]; Available from: http://www.itis. gov/servlet/SingleRpt/SingleRpt?search topic $=$ TSN\&search_value $=26824$.

9. Karuniawan A. Cultivation status and genetic diversity of Yam Bean (Pachyrhizus Erosus (L.) Urban) in Indonesia. Göttingen: Cuvillier Verlag; 2004.

10. Sørensen M. Yam bean: Pachyrhizus DC. Rome: IPGRI; 1996.

11. Niness KR. Inulin and oligofructose: what are they? J Nutr. 1999;129(7 Suppl):1402S-6S.

12. Muaris Hindah. Kudapan. Jakarta: Gramedia Pustaka Utama; 2004.
13. Surtiningsih. Cantik dengan bahan alami: cara mudah, murah dan aman untuk mempercantik kulit. Jakarta: Elex Media Komputindo; 2005.

14. Rahayu T. Aneka resep ampuh ramuan tradisional penumpas kanker, hepatitis, \& diabetes mellitus. Yogyakarta: Araska Publisher; 2011. p. 116.

15. Moongngarm A, Trachoo N, Sirigungwan N. Low molecular weight carbohydrates, prebiotic content, and prebiotic activity of selected food plants in Thailand. Advance Journal of Food Science and Technology. 2011;3(4):269-74 